IZA DP No. 6433

Skill Based Immigrant Selection and Labor Market Outcomes by Visa Category

Abdurrahman Aydemir

March 2012 


\title{
Skill Based Immigrant Selection and Labor Market Outcomes by Visa Category
}

\author{
Abdurrahman Aydemir \\ Sabanci University \\ and IZA
}

\section{Discussion Paper No. 6433 \\ March 2012}

\author{
IZA \\ P.O. Box 7240 \\ 53072 Bonn \\ Germany \\ Phone: +49-228-3894-0 \\ Fax: +49-228-3894-180 \\ E-mail: iza@iza.org
}

Any opinions expressed here are those of the author(s) and not those of IZA. Research published in this series may include views on policy, but the institute itself takes no institutional policy positions.

The Institute for the Study of Labor (IZA) in Bonn is a local and virtual international research center and a place of communication between science, politics and business. IZA is an independent nonprofit organization supported by Deutsche Post Foundation. The center is associated with the University of Bonn and offers a stimulating research environment through its international network, workshops and conferences, data service, project support, research visits and doctoral program. IZA engages in (i) original and internationally competitive research in all fields of labor economics, (ii) development of policy concepts, and (iii) dissemination of research results and concepts to the interested public.

IZA Discussion Papers often represent preliminary work and are circulated to encourage discussion. Citation of such a paper should account for its provisional character. A revised version may be available directly from the author. 


\title{
ABSTRACT \\ Skill Based Immigrant Selection and Labor Market Outcomes by Visa Category*
}

\begin{abstract}
Attracting skilled immigrants is emerging as an important policy goal for immigrant receiving countries. This article first discusses the economic rationale for immigrant selection. Selection mechanisms of receiving countries are reviewed in the context of deteriorating labor market outcomes for immigrants across destination countries which fuels the debate on selection. Next, the variation in immigrant characteristics across countries and visa types is discussed. The article then reviews the evidence on labor market outcomes of immigrants by visa category that portrays the experiences of countries with different selection mechanisms and underlines the challenges for realizing aimed benefits of a skill based immigrant selection policy.
\end{abstract}

JEL Classification: J61, J68

Keywords: immigration, selection, immigration policy, visa category, point system

Corresponding author:

Abdurrahman Aydemir

Faculty of Arts and Social Sciences

Orhanli, Tuzla

34956 Istanbul

Turkey

E-mail: aaydemir@sabanciuniv.edu

\footnotetext{
* Forthcoming in the International Handbook on the Economics of Migration. I would like to thank the anonymous referee and the editors, Amelie F. Constant and Klaus F. Zimmermann, for their suggestions on earlier drafts of this paper. Usual disclaimers apply.
} 


\section{Introduction}

The growing role of skills in today's knowledge based economies and the aging of populations that emerge as a result of decreased fertility and longer life expectancy have substantially increased the importance of immigration for many countries making it one of the top policy priorities. Among many impacts of immigration on the receiving countries economic consequences attract a lot of attention and form an important part of the debate on immigration. Receiving countries face important decisions in terms of the size of immigrants to be admitted, the composition in terms of various visa categories, and the selection mechanism that determines admission within each category. These decisions, in turn, have important implications for the economic consequences of immigration in the receiving countries.

A large number of studies within the economics literature focus on the selectivity of immigrants in terms of skills they bring to the host countries. Studies that focus on the selectivity of immigrants relative to the source country populations aim to uncover the factors that determine the migration decisions. Other studies focus on the skill levels of immigrants relative to the host country population since these relative skills play an important role in shaping the resulting economic impacts of immigration.

While the earlier studies mainly focused on the role of the economic incentives for migration in determining the skill levels of immigrants, what is called the "selfselection" of immigrants (Borjas, 1987), an increasing number of studies started to 
underline the important role the visa selection rules play in shaping the skill of immigrants that are admitted to a host country (Cobb-Clark 1993, Aydemir 2006). A related literature is also emerging on the labor market outcomes of immigrants admitted under different visa classes that provides comparative evidence on the labor market experience of different types of immigrants. The results from these studies are important to policy makers since the composition of immigrants in terms of various visa classes and the rules that determine eligibility within each class are important policy parameters.

This article focuses on the evidence provided in the literature regarding the cross country variation in immigrant characteristics, the role of visa selection rules in this variation, and the labor market outcomes of immigrants across visa categories. In the next section the article discusses the economic rationale for immigrant selection. Recent trends in immigrant outcomes that show deterioration over time is discussed next which fuels the debate on immigrant selection and brings to the front increasing the skill levels of immigrants as a solution. In section 4 selection mechanisms of major immigrant receiving countries are reviewed with an eye on how the policy decisions have evolved over time as the immigrant outcomes deteriorated. Whether immigrants selected for their skills perform better in the market, as the skilled immigration policies aim, is discussed in section 5. The last section concludes.

\section{Economic rationale for immigrant selection}


Immigration changes the supplies of factors of production in the host country. The literature primarily focuses on the role of immigration in increasing the labor supply in the receiving country. An increase in the capital stock through immigration is also possible if immigrants bring savings with them. Economic theory is interested in the surplus income generated through immigration and how this surplus is distributed among various factors of production.

Consider an economy where production function includes capital and two types of labor, skilled and unskilled. If the supply of capital is perfectly elastic, so that returns to capital are fixed, then the impact of immigration on the earnings of workers depends on skill composition of immigrants relative to native born. If the skill distribution of immigrants is identical to natives, immigration does not alter the wage structure of workers. Only if the relative skills of immigrants are different from the native born then the immigration will have an impact on the wage structure. The wages of native skill group in which immigrants are over represented will decline while the wages of the other skill group increases (Borjas, 1999). Accompanying the change in the wage structure an immigration surplus will be generated which is defined as the change in the national income that accrues to natives. The more the immigrant flow differs in its skill composition from natives the higher will be surplus. If, for example, the native work force is relatively unskilled gains from immigration will be maximized when only skilled workers are admitted.

The assumption that capital supply is perfectly elastic is unlikely to hold in the short run since firms generally adjust to shocks with a lag. The assumption of a fixed capital stock leads to different predictions for the impact of immigration. In this context even when the relative skills of immigrants are identical to natives immigration reduces 
the total earnings of native workers while increasing the rate of return to capital. Even though the wages of workers fall the increases in incomes of capitalists more than offsets this fall resulting in positive immigration surplus. The skill mix of immigrants that maximizes the surplus depends on the relative skill composition of immigrants, demand elasticity of skilled and unskilled workers, and the complementarities of different types of labor with capital. Therefore, the skill mix of immigrants that maximize the surplus will be specific to a country. Importantly, under both elastic and inelastic capital stock assumptions the immigration surplus arises only if the wage structure of natives change leading to a fall in the earnings of at least one group of native workers.

Borjas (1999) calculates the immigration surplus for the US economy under both the inelastic and perfectly elastic capital assumptions and concludes that surplus is on the order of 0.1 to 0.4 percent of the national income when the labor supply increases 10 percent due to immigration. However, Borjas points out that this small overall impact masks large distributional impacts of admitting relatively skilled or unskilled immigrants. For example, under the assumption of a perfectly elastic capital and a definition of unskilled workers as high school dropouts, the simulated impact of the above increase in the labor supply leads to falls in earnings of unskilled workers between 1.2 and 6.1 percent while resulting in very small gains for skilled workers. The capitalists gain the most where their incomes increase by between 2.4 and 11.8 percent. When capital is perfectly inelastic earnings of both types of workers decline, by as much as 4.4 percent for the skilled and 6 percent for the unskilled, while income of capitals increase 11.8 percent. Therefore, the small change in the immigration surplus in the US context is accompanied by a sizeable redistribution of wealth between the 
owners of factors of production. Aydemir and Borjas (2007) provide evidence that the distributional impact of immigration is closely linked to the immigration policies of the host countries. Canadian high skill immigration policy leads to a narrowing of the wage inequality in Canada as a result of reductions in the wages of highly skilled while in the US wage inequality increases due to a predominantly low skill immigrant intake reducing wages at the bottom of the skill distribution. On the other hand, Hijzen and Wright (2010) estimate very small impacts of immigration on aggregate welfare in the UK along with small wage impacts. In terms of which immigration policy maximizes the immigration surplus, Borjas (1995a) argues that when the native work force is predominantly skilled, capital-skill complementarity may justify the admission of a skilled immigrant flow in the US context.

The framework outlined above for predicting the potential impacts of immigration on native wages and the resulting surpluses assumes an equilibrium model with no unemployment. Extension of this framework to one where there may be unemployment is considered by Bauer and Zimmermann (1997). In this framework with heterogeneous labor where skilled labor is in a competitive equilibrium and unskilled labor is in a disequilibrium with unemployment the immigration surplus depends on the combination of wage and employment effects. Simulations of this model with German data predict significantly larger gains for natives with a skilled immigrant intake compared to an unskilled one.

Thus, above discussion indicates that benefits from immigration in the form of immigration surplus mainly arise from complementarities between immigrant skills and native factors of production. Selection of immigrants based on the skills which shapes the relative skills of immigrants compared to natives is therefore crucial in determining 
the economic impacts of immigration. Selection of immigrants then can be rationalized to maximize the surplus or to gauge the distributional consequences of immigration on factors of production.

The calculation of immigrants' surplus makes important assumptions such as no increase in capital stock through immigration, existence of a wage impact of immigration, assumptions about various elasticity parameters. Surplus calculations also ignore important potential externalities of immigration that are hard to measure. For example, expansion in the size of the aggregate economy due to immigration may generate external returns for factors of production. Skilled immigrants may also generate positive spillover effects and increase productivity of existing workers. On the other hand, immigration in densely populated areas may significantly increase the cost of providing public services and require new investments in infrastructure financed through higher taxes.

Another important aspect of immigration that receives a lot of attention in policy debates is the fiscal impacts of immigrants. Since most immigrants are working age, they may contribute to the government finances by widening the tax base. This potential contribution is especially important in countries with an aging population and increasing cost of supporting elderly. In these countries continued immigration flows may help reduce the old-age dependency ratios and also increase birth rates since immigrants usually have higher fertility rates. However, the contributions of immigrants to government revenues crucially depend on their gainful employment. If immigrants experience problems in adjusting to the host country labor market, rather than contributing to revenues they may become beneficiaries of government transfer 
programs. Thus, the immigration policy may want to take into account immigration surplus net of these fiscal effects.

Studies on fiscal impacts of immigrants make the important assumption that immigration has no impact on native employment and wages. Under this assumption overall fiscal impact of immigration is found to be quite small, usually less than plus or minus 1 per cent of the GDP. The fiscal contributions of immigrants, however, vary significantly by the skill level of immigrants. The evidence suggests that skilled immigrants pay more taxes and they are less likely to use government services. In the US context Smith and Edmonston (1997) and Storesletten (2000) both report a negative net present value, discounted sum of contributions and costs to the public coffers, for lower educated immigrants while for more educated immigrants the net present value is positive. Borjas and Hilton (1996) and Fix and Passel (2002) also provide evidence that low skilled immigrants earn lower wages, pay relatively smaller amounts of taxes, benefit from subsidized health care more frequently. Barrett and McCarthy (2008) find an inverse relationship between welfare receipt and education level in Ireland and the UK, and argue that a more favorable selection of immigrants at the point of entry will lead to lower welfare dependency among immigrants. A similar conclusion is reached by Riphahn (2004) that studies take up of welfare among immigrants and natives in Germany. Ekberg (1999) reports a deterioration in the net contributions of immigrants in Sweden over time which is linked to the declining labor market prospects of immigrants'. Thus, above findings of larger positive fiscal contributions for highly skilled migrants and significant costs associated with low skilled immigrants would support a policy that favors skilled immigrants. 
The importance of human capital in long term growth provides another case for selecting skilled workers. Skilled immigrants that are involved in development of new products and related research activities may contribute to competiveness and growth of industries (Wadhwa et al. 2008). Studies find a positive relation between the growth in innovation and high skill immigration (e.g. Hunt, 2011, Kerr and Lincoln, 2010, Hunt and Gauthier-Loiselle, 2010). Kerr and Lincoln shows that more than half of the net increase in the US science and engineering labor force since 1995 was due to immigrants. If high skill immigrant workers increase the scale of activities related to innovation above the level that would otherwise occur without immigrants then the host country may enjoy stronger growth. There is some evidence, though, of displacement of natives from science and engineering $\mathrm{PhD}$ fields due to the presence of immigrants (Borjas, 2009). Along with these potential benefits of a skilled immigrant intake there is growing concern and debate about the labor market prospects of immigrants in some countries where skill levels of immigrants are at the center of the discussions.

\section{Deteriorating labor market outcomes of immigrants across}

\section{receiving countries}

In many receiving countries inferior labor market outcomes is observed among immigrants relative to natives. Causa and Jean (2007), investigating the labor market outcomes of immigrants in Austria, Belgium, Denmark, Finland, France, Germany, Italy, Spain, Portugal, Australia, US, and Canada, conclude that immigrants significantly lag behind comparable natives in terms of wages or employment, or both. Similar evidence is provided for Austria, Belgium, Denmark, France, Ireland, Portugal 
by Rosholm et al. (2006) that shows lower participation, employment, earnings and higher unemployment for immigrants, especially for those originating outside the EU15 countries. The results also indicate on average inferior labor market outcomes for immigrants in these countries when they are compared to natives with similar age and education.

In addition to these inferior outcomes observed among the general immigrant populations in the OECD countries, there has also been a marked deterioration in the performance of immigrants over time for some receiving countries. The relative performance of immigrants are documented either as unadjusted or adjusted differentials. Unadjusted differentials compare the outcomes of immigrants relative to natives without controlling for human capital characteristics while adjusted differentials refer to comparisons between immigrants and natives with similar observed characteristics such as age and education. These comparisons show that there has been a substantial decline in entry wages and employment levels of immigrants in the US, Canada, the UK, Denmark and Sweden (see e.g. Borjas (1985, 1995b), Lubostky (2007), Borjas and Friedberg (2009) for the US; Baker and Benjamin 1994, Bloom, Grenier, and Gunderson 1995, Grant 1999, Aydemir 2003, Green and Worswick 2003, Li 2003, Aydemir and Skuterud (2005) for Canada; Clark and Drinkwater (2008) for the UK; Rosholm, Scott, and Husted (2006) for Denmark and Sweden).

In the US context Borjas (1999) reports that unadjusted earnings of immigrants were about 4 percent more than natives in 1960 but they earned 16.3 percent less by 1990. The adjusted wage differentials were 1.3 percent higher earnings in 1960 compared to 10 percent lower earnings by 1990 . Similar trends are observed among immigrants that arrived over the last five years prior to each decennial Census. Borjas 
notes that a substantial fraction of the decline in relative earnings of immigrants can be explained by changes in observable socioeconomic characteristics of immigrants, especially educational attainment. Deteriorating labor market outcomes for more recent immigrants in Canada are also widely documented. The deterioration in the Canadian context is remarkable since it was observed despite an upward trend in the educational attainment of Canada's new immigrants over this period. Li (2003), focusing on earnings of immigrants one year after arrival, shows that differential in unadjusted earnings between natives and immigrants grew with each arrival cohort over the 19801996 period. Aydemir and Skuterud (2005), comparing the earnings of immigrants that arrived over 1966-2000 to natives with similar education and experience, find that entry earnings of Canada's immigrant men and women declined with each successive cohort throughout the period from the late 1960s to the early 1990s. Immigrant men arriving by the early 1990s had earnings that were $61 \log$ points lower than the entry earnings of immigrant men arriving in the late 1960s. Immigrant women experienced a very similar deterioration in their entry earnings with a comparable differential of 63 log points. For those arriving in latter half of the 1990s there was a modest reversal where the differential declined to $51 \log$ points for both men and women. Aydemir (2003) provides evidence of deterioration also in the employment and labor force participation rates of recent Canadian immigrants. Rosholm, Scott, and Husted (2006) find that immigrants had lower employment probabilities in Denmark and Sweden in 1985 compared to natives and their relative position further deteriorated between 1985 and 1995. For Australia Teicher et al. (2002) find declining labor force participation rates over successive cohorts of immigrants from non English speaking countries. McDonald and Worswick (1999), on the other hand, focus on immigrants arriving in Australia by 
early 1990s and find no decline in adjusted earnings of immigrants compared to natives. Accompanying the decline in labor market prospects, the use of social assistance by immigrants has also been on the rise in various countries (Hansen and Lofstrom, 2003 for Sweden, Borjas and Trejo, 1991 for the US, Baker and Benjamin, 1995 for Canada).

The evidence from receiving countries that immigrants in general perform worse in the labor market compared to natives and the relative performance of immigrants has been declining over arrival cohorts is concerning for policy makers. The concern arises since immigrants with low labor market prospects may become a net fiscal burden for the receiving countries. The increased competition in the labor market especially for the lower skilled natives may also lead to a negative public opinion about immigration (Bauer et al. 2000) $)^{\mathrm{ii}}$. The positive relationship between labor market performance and skills of immigrants leads to policy prescriptions that favor a more skilled immigrant intake. Skilled immigrants are expected to have a more positive net fiscal contribution and public opinion in receiving countries tends to be more positive towards skilled immigration. In this context, the skilled immigration has been raising in the policy agendas of the receiving countries.

\section{Immigration policies}

For the economic consequences of immigration skill levels of immigrants is an important determinant and, thus, draws a lot of attention in the debate on the design of policies. Skill levels of immigrants widely differ across receiving countries. Grogger \& Hanson (2011) present the share and skill composition of all international migrants residing in OECD countries by broad destination regions in 2000 based on data by 
Docquier and Marfouk (2006). While North America (Canada, Mexico, and the US) received $51.4 \%$ of all migrants destined to OECD in 2000, the region received $65.5 \%$ of all migrants with tertiary education and $35.2 \%$ of those with primary education. Europe received $38.4 \%$ of all immigrants, $23.6 \%$ of immigrants with tertiary education, and $56 \%$ of those with primary education. Australia and Oceania (Australia, Japan, New Zealand, and Korea) received $10.2 \%$ of all immigrants, $10.9 \%$ of tertiary educated immigrants, and $8.8 \%$ of those with primary education. Thus, immigrants destined to North America were disproportionately highly educated while those destined to Europe was disproportionately lower educated.

There is also large variation in skill levels of immigrants within these broad regions (OECD, 2005). In the North American context the US received $44.2 \%$ of the total immigrant stock in the OECD and a slightly higher share of the tertiary educated immigrants at $45.2 \%$. Canada, on the other hand, received $7.5 \%$ of the all immigrant stock, and $11.2 \%$ of the tertiary educated immigrants. In the European context Germany's share of immigrant stock was $12.3 \%$ while the country's share among tertiary educated was much lower at $7.6 \%$. UK contrasts with German case with $5.5 \%$ of all immigrant stock and $7.6 \%$ of the tertiary educated. Similar differences exist between Australia and New Zealand. Australia's share of immigrant stock stands at 4.8 $\%$ and while the country's share among tertiary educated is $8.1 \%$. Corresponding numbers for New Zealand is $0.8 \%$ of the immigrant stock and $0.9 \%$ of the tertiary educated. Much higher shares of tertiary educated immigrants is notable in destination countries such as Canada and Australia that favors skilled immigrants in admission decisions. 
Studies interested in the observed variation in education levels of immigrants across receiving countries discuss the relative returns to skills across host countries as an important determinant of skill selectivity (Borjas 1987, Chiswick 1999, Grogger and Hanson 2011). In their analysis of sorting of immigrants across destinations Grogger and Hanson (2011) find that relative stock of more-educated immigrants in a destination increases with the absolute earnings difference between high and low-skilled workers. This underlines the importance of labor market opportunities in attracting a higher skilled immigrant flow. Differences in skill compositions of immigrants across destination countries within broad regions, such as differences between Canada and the US, indicates on the other hand that immigration policies geared towards selecting highly skilled immigrants also play a very strong role in determining the selectivity of immigrants (Aydemir 2006). Immigration policies are complex, multi-dimensional structures with some components favoring and others hindering a more skilled immigrant intake.

In general the immigration policy is shaped by social, economic, humanitarian and political factors at the national and international levels. The policy reflects the priorities in admissions of immigrants and regulates the treatment of legal and illegal immigrants. Some countries may also favor temporary migration over giving rights to individuals for permanent residence in the country. The size of temporary migrants, most of them working in low skill occupations, is large exceeding the size of permanent migration in many countries (OECD, 2008).

Priorities in admissions of immigrants with permanent residency rights are reflected by the allocation of visas across different types and the rules that determine admissibility within each visa type. Immigrants are admitted for family reunification 
purposes, on humanitarian grounds or for economic reasons. Number of immigrants to be admitted under these categories may either be unrestricted or subject to a quota. Reflecting different priorities regarding permanent immigrants, allocation of total immigration across visa types differs across destination countries. About $44 \%$ of total permanent migration in OECD countries was family related in 2006 while labor migration (excluding accompanying family members of immigrant workers) accounted for $14 \%$ of all migration (OECD, 2008). While the US puts significant weight on family related migration economic goals are given priority in Canada and Australia. Migration to Europe, on the other hand, is characterized by the more significant role humanitarian-based migration plays and the higher share of free migrants originating from the European Economic Region.

Labor migration, excluding accompanying family members, accounts between $20 \%$ to $30 \%$ of total migration in Canada, New Zealand, and Australia while the corresponding figure is only $6 \%$ in the US. Excluding free migrants ${ }^{\mathrm{iii}}$ labor migration in Europe is above $30 \%$ in Denmark and the UK, much less prevalent in other countries, around $15 \%$ in Finland, Belgium, and Germany $10 \%$ or lower in Norway, France, Netherlands, Switzerland, Austria and Sweden. In the US and European countries where labor migration is much less prevalent family related migration accounts around $60 \%$ or more of total migration. Humanitarian migration has a significantly higher weight in some European countries. Compared to $17 \%$ of total migration in the US and Canada, and $9 \%$ in Australia, $32 \%$ of total migration in Netherlands, $43 \%$ in Sweden are admitted based on humanitarian grounds. In the rest of Europe humanitarian migration is much less significant with shares that are either similar to the North American context or lower. 
The policies that determine eligibility for permanent type immigration and regulations regarding temporary workers also have implications for illegal immigration. When legal immigration is too costly or infeasible many individuals are channeled into illegal means for entry. Also, those who entered through legal means as temporary immigrants may overstay and become unauthorized workers. For receiving countries the intensity of policing of the borders against illegal immigration and deportation of illegal workers, the level of fines for employers employing unauthorized workers are policy choices that affect the size of illegal migrants in a country (Hanson, 2010 discusses illegal immigration as a policy choice). Illegal immigration is sizable in many countries. In the United States, Passel (2006) estimates that illegal immigrants account for $30 \%$ of the foreign born population. Estimated annual net inflow of unauthorized immigrants is between 500-550,000 per year for the US (OECD, 2008). In the European Union, the gross annual inflow of illegal immigrants is estimated to be around 650,000 to 800,000 individuals a year (Jandl, 2003). Countries with large illegal immigrant populations often offer amnesties which provide another channel of permanent migration ${ }^{\text {iv }}$. Thus, for immigrant receiving countries the priorities in admissions and regulations for temporary, permanent, and illegal immigrants jointly shape the characteristics of the immigrant stock in a country.

Further heterogeneity across destination countries arises when selection of labor migrants is considered. The US allows highly skilled temporary workers through a number of different types of visas, H-1B category being one of the most well-known. Skilled workers can gain permanent status with the sponsorship of a US based employer. These mostly include individuals with extraordinary ability, outstanding professors, researchers, professionals with advanced or bachelor's degrees. Other 
traditional immigrant countries, on the other hand, rely on a points test for selecting labor migrants. Canada was the first country to launch a points test for selecting immigrants in 1967. Australia started using points system in early 1970s, followed by New Zealand in 1991. Points test in general assesses the applicant's age, education, intended occupation, work experience, and language ability. Existence of pre-arranged employment, presence of close relatives, prior work experience or education in the country of destination also leads to extra points. Applicants are required to achieve a minimum number of points for admission

Although points tests share some common features there are important differences in their design across countries. In the Canadian points system traditionally no selection factor is mandatory and an applicant can compensate for low points in an assessed factor by gaining high points from another factor ${ }^{\mathrm{vi}}$. In the Australian system certain factors are mandatory. Australia requires vocational level English, the occupation to be on the skilled occupation list, and the post-secondary qualifications to be formally assessed before application. The work requirements are also waived for international students who gained a degree from an Australian education institution; extra points are provided for qualifications obtained in Australia and for spouse skills. In Australia immigrants, excluding those admitted on humanitarian grounds, are also denied access to most social welfare benefits for the first two years after arrival (Richardson and Lester, 2004). Selection criteria in New Zealand points system has many features similar to the Australian system with pre-migration language screening, mandatory pre-migration qualifications recognition, bonus points for former international students with New Zealand qualifications, additional bonus points for occupations in demand (Birrell et al. 2006). 
Following the lead of traditional immigration countries UK now also uses a points system for selecting workers based on skills. The system was first launched in 2002 as the Highly Skilled Migration Program which was later replaced by the pointsbased management system in 2008. The system has similarities to the points system used by Canada and Australia as it awards points for age, work experience, qualifications, and spousal characteristics. Similar to the Australian system language is a required characteristic; applicants who cannot pass the language tests cannot qualify for the permits. Applicants also have to demonstrate maintenance through possession of sufficient funds to support the migrant in the UK. Unlike the other two systems the UK system also rewards those with significant past earnings (Ruhs, 2008). Another important difference is that the points-based management system in the UK grants work permits that are temporary which are intended to lead to permanent settlement.

The introduction of the points-based systems in the UK is part of a growing interest within the European context for designing new policies to attract highly qualified workers. In Netherlands, Germany, France, Ireland, Denmark immigration policy changes were introduced between 2006-2007 aimed at becoming more proactive and selective for attracting high-skilled migrants (OECD, 2008) $)^{\text {vii }}$. For example, Denmark introduced a new points based green card scheme for attracting skilled workers where points may be accumulated based on earnings, qualifications, and a shortage list. Netherlands also introduced a points based system in 2008 while Austria is planning the implementation of a similar system (OECD, 2011). Eastern European countries are also actively encouraging immigration by the highly skilled. Czech Republic, for example, initiated a similar approach in 2008 issuing green cards with possibility of application for permanent residence after three years. 
In traditional migration countries Canada, Australia, and New Zealand selection through the points system automatically leads to permanent residence rights. In the European context points based selection is being introduced into already existing work permit systems and often allows temporary residence that may lead to permanent rights. The existing points based selection systems are also undergoing several changes with developments in the labor markets and as the countries try to improve their systems. Through these changes regional authorities are gaining importance, such as in the Canadian case where provinces are becoming more active in the immigrant selection. Also, international students at destination countries are increasingly seen as potential future labor migrants and countries are relaxing international student regulations some allowing them to work while studying or allowing them to stay and take up work after graduation (OECD, 2008).

Source countries of the international students are also starting to implement policies to attract expatriates. Various programs were implemented in China since 1990 to encourage highly talented Chinese expatriates to return, placing priority on scientists, academics, and entrepreneurs (Constant et al., 2011). China also has been making significant investments in the higher education sector and has recently seen large increases in the number of international students from other parts of the world.

The demand for skilled workers is likely to increase in future as receiving countries increase their efforts to recruit skilled immigrants. Developing countries are also adopting human capital policies that emphasize retaining and attracting talent that spurs growth. Thus, in this context of increasing demand the supply of skilled immigrants becomes an important issue. 
There are already some signs that skilled immigrants host countries are trying to recruit are in short supply. Despite the efforts of receiving countries to reverse the trend, the large deterioration in entry earnings of immigrants across arrival cohorts, especially for the highly educated, provides evidence that the supply of foreign trained skilled workers that easily adapt to the host country labor markets is quite limited. Receiving countries are competing to attract skilled workers by easing the restrictions on the admission of these workers and providing incentives for migration, such as through tax breaks.

As the competition for skills spreads highly skilled workers are increasingly more able to choose among alternative destinations. The expected earnings, the social rights and permanent residence opportunities are likely to be important factors that shape these choices. The extent to which skilled immigrants can easily adapt to the labor markets of receiving countries determine whether host countries can benefit from and retain existing immigrants, and attract others. The skilled immigrants' labor market success relative to other visa types is also crucial since this forms the basis for pursuing a skilled immigration policy.

Above discussions highlight that receiving countries differ significantly in their admission procedures and the rights granted to the skilled workers in the host country. The impacts of these differences for the characteristics of the skilled workers and their labor market success are addressed in the next section.

\section{Impact of host country selection on immigrant characteristics}

\section{and labor market outcomes}

\section{a. Immigrant characteristics}


The selection mechanisms discussed above aims to generate immigrants that are more skilled than those admitted under family preferences or humanitarian grounds. A number of studies focus on whether skill based admission policies indeed generate more skilled immigrants.

The different policy choices between Canada and the US in the North American context provide an interesting comparison. Both countries' immigrant admissions were based on a national origin quota system that was abandoned by the early $1960 \mathrm{~s}$. The policies started to diverge afterwards, the US making family preferences as the cornerstone of its policy while Canada stressing the skill requirements in its admissions through its points based selection. Using 1980 US and 1981 Canadian censuses Duleep and Regets (1992) compare the characteristics of immigrants migrating from the same region of origin arriving in these two destinations around the same time. Interpreting the differences as an outcome of different policies they conclude that although Canadian immigration policy succeeded in reducing the age at immigration and increasing the language proficiency there is little difference in the educational levels of immigrants in these countries. By pooling all source countries Borjas (1993) also compares these two destinations using 1970/80 US and 1971/81 Canadian censuses and notes that Canada attracted a more educated immigrant flow following the introduction of the point system. However, despite attracting a more educated immigrant pool the educational attainment of immigrants from same source countries are found to be very similar to each other in these two destinations. Borjas concludes that the point system alters the national-origin mix of the immigrant flow toward countries with higher average skills rather than attracting more skilled workers from a particular source country. Antecol et 
al. (2003) extend this analysis by including Australia and use 1990 US and 1991

Australian and Canadian censuses in order to reexamine the consequences of skill-based immigration policies on immigrant outcomes. They find that immigrants in the US have lower language ability, education, and income relative to natives. Language fluency rates and education levels for US immigrants are also lower than Australian and Canadian immigrants arriving around the same period. However, after excluding Latin American immigrants, mostly undocumented migrants with a large share in the US, observable skills of immigrants are similar in the three countries. Thus, their results lead to the similar conclusion that the differences in skill levels in these countries are a result of different country of origin compositions of immigrants.

To attribute the differences in immigrant characteristics across destinations to the immigration policy it is necessary to assume that the applicant pools in these destinations would be identical under the same immigration rules. If this is not true, then across country variation in skill levels will be a function of both the attractiveness of the host countries for potential immigrants (i.e., who applies) and the selection processes (i.e., who is admitted; Aydemir 2006).

Direct evidence of the impact of policy on the characteristics of immigrants is provided by studies that focus on immigrants in a destination country admitted under different visa classes. Barrett (1998) examines the relative skill levels of immigrants admitted under different criteria in the US during $1978-80$ and $1988-90$ periods. Using expected earnings based on reported occupations at the time of admission as a skill measure Barrett finds that within a source country immigrants admitted under family preferences have lower skills than employment based immigrants. Using administrative records Jasso and Rosenzweig (1995) examine the occupational status of US male 
immigrants admitted in 1977. US Immigration and Naturalization data used in the analysis allows identification of immigrants entering as spouses of US citizens and employment immigrants whose admission is based on occupational skills. They also find that at admission the skills and earnings levels of employment-based immigrants were significantly higher than those of the immigrants admitted as the spouses of US citizens. These gaps remain after netting out differences in the ages, pre-immigration US experience and origin country composition of the two groups.

Above studies for the US have to rely on occupation data to infer skill differentials between immigrants admitted under different visa types. Aydemir (2011) uses Longitudinal Survey of Immigrants to Canada that reports the visa category, education and language ability at the time of admission for immigrants arriving in Canada over 2000-2001. A comparison of the education levels shows that male skilled worker class immigrants have 3.9 and female skilled workers have 3.4 more years schooling than their counterparts in the family class. Skilled worker class immigrants also report higher language ability in both Canadian official languages. Interestingly, the average schooling levels of immigrant national-origin groups arriving in Canada and the US over this period indicate, in general, an advantage of about one year for Canada while for some source regions US had higher education levels (Aydemir and Sweetman, 2007). Given the large share of skilled worker class immigrants in Canada these results show that, without the point system, average schooling level among immigrants in Canada would have been much lower than that in the US ${ }^{\text {viii }}$.

Aydemir (2011) also examines the within-country and across-country components of the skill differentials between immigrants visa classes. For both males and females, over $90 \%$ of the schooling differential between skilled worker and family 
class immigrants is due to differences within national origin groups and less than $10 \%$ is due to differences in national-origin composition across the two classes. This result shows that the point system generates a higher-skilled immigrant flow primarily by selecting more skilled immigrants within countries of origin rather than changing the country of origin composition ${ }^{\mathrm{ix}}$.

The data also allows identification of principal applicants, those who apply for migration on their behalf when the migrating unit is a family. In the case of skilled workers, principal applicant refers to the person who is assessed by the points test based on individual characteristics and the decision for the dependants rests on this assessment. Human capital characteristics of the skilled-worker dependants are not assessed by the points test. Examining the education levels of principal applicants and dependants across different visa classes, the results show that the positive selection among skilled workers is achieved by directly selecting higher-skilled principal applicants who are assessed by the point system and also indirectly through higherskilled spouses.

Beach et al. (2007) use the administrative Canadian Landings Database to examine how changes in policy levers affect the skill characteristics of immigrant arrivals over 1980-2001 period. They find that increasing the proportion of skillevaluated immigrants raises the average skill levels and increasing the point system weights on a specific skill dimension serves to raise average skills levels in this dimension among the principal applicants. Green and Green (1995) examine the effects of changes in Canadian immigration policy on the occupational composition of immigrants. These occupations refer to intended occupations reported by immigrants at the time they become permanent residents. By comparing the occupational composition 
of the immigrant cohorts before and after the point system came into effect they find that the point system shifted the inflow away from low skilled occupations towards professionals. Increases in the proportions entering under the family or refugee classes cause reductions in the share of high skill occupations. Moreover, changing the points awarded for occupational demand factor in the points test does alter the occupational mix of assessed immigrants.

In the Australian context skill-based immigrants have higher language ability and education than family based immigrants (Cobb-Clark, 2000). Chiswick et al. (2006) also examines language skills by visa class. Their findings show that skill-based immigrants have higher language proficiency shortly after arrival followed by familybased immigrants and those admitted under humanitarian grounds. The differences, while smaller, persist when other characteristics such as age at migration, education, family characteristics are controlled for. Following a cohort of immigrants over their first 3.5 years in Australia they find that the differences in speaking proficiency by visa category diminishes with duration in Australia, disappearing 3.5 years after immigration. For reading and writing skills the differences by visa category diminishes over time, but they do not disappear. Constant and Zimmermann (2005b), on the other hand, examine the relationship between the legal status of the immigrants (work permit, refugee, and kinship) and their characteristics upon arrival in Denmark and Germany. In absence of a skill-based selection in these countries they find that indicators of labor market success, such as education and work experience, play a small role in distinguishing labor migrants from immigrants admitted based on kinship and humanitarian grounds. 
Thus, above results show that screening immigrants based on their skills generates a more educated and language proficient immigrant pool and shifts the intended occupations of immigrant away from low skill occupations. In creating a higher skill level among assessed immigrants the ability of the points system to select higher skilled individuals within countries of origin also plays a major role. In the next section we examine the evidence regarding the extent to which these higher skill levels lead to superior labor market outcomes.

While interpreting the differences in outcomes among the highly skilled it is important to keep in mind that significant differences in selection criteria across countries exists despite some similarities. For example, although both countries use a points test, in Australia certain factors are mandatory and some qualifications are tested before application while in Canada mandatory factors and testing are not traditionally used. Unlike these two countries, in other countries such as the US and the UK, employment based immigrants usually work as temporary workers initially before they can adjust their status to gain permanent residency rights. Hence, these immigrants already have strong attachment to the labor market when they qualify for permanent residency.

\section{b. Labor market outcomes}

In the US context Duleep and Regets (1992) investigate the earnings of immigrants from Asia, the UK and Europe using 1980 Census data. They find that as the percent of family-based immigrants in an arrival cohort increases the initial earnings of immigrants falls indicating higher entry earnings for occupation (employment) based immigrants. 
However, the expected earnings growth of the family-based immigrants is higher than occupation based immigrants, therefore, initial earnings differences diminish with time spent in the country. Extending this analysis to a larger set of source regions Duleep and Regets (1996) confirm their previous findings. Using administrative data Lofstrom and Hayes (2011) compare the earnings of foreign temporary H-1B visa holders, who can pursue an employment-based permanent residence visa, to the US born workers in science, technology, engineering and mathematics occupations. H-1B workers are found to have higher earnings than their otherwise observationally similar US born counterparts. Jasso and Rosenzweig (1995) examines whether initial occupational (earnings) advantage of employment immigrants erodes over time. They find that ten years after immigration, the differential in average occupational earnings between the employment immigrants and those admitted as spouses of US citizens is 60 percent of what it was at the time of admission. This is partly due to a downward mobility among the employment based immigrants and more importantly to the occupational upgrading among marital immigrants. Thus, Jasso and Rosenzweig conclude that the distinction between family reunification and employment based immigrants may be less important if post-migration experience of these two groups is taken into account.

The availability of data with visa class information led to a richer set of results in the Canadian context regarding the relative labor market performance of immigrants. Aydemir (2011) analyzes the differences in labor force participation (LFP), employment and earnings of immigrants across visa categories relative to the family class immigrants over the first two years after arrival. The study also investigates differences between principal applicants and their dependents. This distinction is important because 
it is mainly the characteristics of the principal applicants that are assessed by the points test for skilled based immigrants while the dependants are not subject to a points test ${ }^{\mathrm{x}}$.

First, the average entry outcomes are presented across different types of immigrants without any controls for either demographic or human capital characteristics. For both genders, among both principal applicants and dependants, the LFP and employment rates are in general similar or lower for skilled workers compared to their counterparts in the family class. For principal applicants, however, the earnings levels for skilled workers are substantially higher. Considering all types of visa classes, including refugees and business class immigrants, the groups that have the least favorable outcomes at entry in terms of LFP and employment register the largest gains reducing the gaps between visa classes ${ }^{\mathrm{xi}}$. However, the gaps in earnings persist. These results show that much higher schooling levels and higher language proficiency among skilled workers do not translate into more favorable outcomes especially for male principal applicants at the LFP and employment margins.

Controlling for differences in human capital and demographic characteristics of immigrants has limited power for explaining differences in entry outcomes across visa classes. For principal applicants the addition of controls explains about half of the earnings difference between skilled-worker and family class males and about one fifth of the difference for females. Also the profiles over time remain largely unchanged with these additional controls.

De Silva (1997) and Wanner (2003), examining the earnings differences between visa classes, report significant earnings advantages for the skilled workers. Wanner reports no evidence of convergence between visa classes in mean earnings levels, unadjusted for characteristics, over time. Immigrant characteristics can account 
for only about less than 40 percent of the earnings differential between skilled workers and other visa classes. Both studies report a reduction in gaps over time. As opposed to previous studies that explores convergence between immigrant visa classes, Li (2003) estimates the number of years it takes for immigrant cohorts to achieve earnings parity with an average native born. The results show that recent immigrant cohorts, despite their higher education levels, earned less initially than earlier cohorts. Controlling for the education, language capacity, and age at immigration immigrants from Europe and the US took less time to catch up with the average earnings of Canadians than those from Asia and Africa. Immigrants who came as family class immigrants took the longest to achieve parity while skilled worker principal applicants required the least time. Among males education, age, the class of admission and other background factors only account for 15 percent of the variation in immigrants' catch-up capacity, 24 percent for females.

Small explanatory power of the human capital characteristics in the Canadian context is an important result. Exploring this issue Aydemir (2011) finds that three main characteristics assessed by the points system, education, experience and language do not have significant returns in the first two years after arrival ${ }^{\mathrm{xii}}$. This result indicates major difficulties in transfer of foreign human capital in immigrants' first few years in Canada. De Silva (1997), while finding larger returns for education and earnings, reports a much lower return to foreign experience compared to Canadian experience ${ }^{\mathrm{xiii}}$. After controlling for demographic and human capital characteristics large unexplained differences remain between visa classes which reflects the importance of unobserved differences across visa classes that the factors assessed by the points system cannot account for. 
In addition to above studies exploring labor market outcomes a number of studies in the Canadian context explore the use of transfer programs and poverty rates. Marr and Siklos (1999), examining the unemployment insurance claims, find that claims rate among immigrants rise rapidly in the first few years after arrival for all visa classes but decline thereafter. Without any controls for human capital characteristics skilled worker principal applicants have the lowest claim rates, followed by family class and refugees. In fact the claim rates of skilled workers five years after arrival is below the Canadian average. Large differentials between skilled workers and other visa classes persist for about ten years following entry, declining in the following years. Picot and Hou (2008), on the other hand, find that poverty levels increased among recent immigrants despite increasing education levels and a higher share of skilled workers. This is driven by the fact that by the early 2000s, newly arriving skilled workers were actually more likely to enter and stay in poverty than family class immigrants.

Australian experience provides an interesting comparison to the Canadian case given some important differences between the two points systems. Cobb-Clark (2000) finds that immigrants selected for their skills (Business Skills, Employer Nomination and points tested Independent immigrants) have higher LFP and employment rates than humanitarian and family based immigrants by 6 months and 18 months after arrival in Australia. After controlling from human capital and other productivity related differences between classes still large differences remain between skill and family based immigrants. Importantly points tested immigrants cannot do as well as employer nominated immigrants who have pre-arranged offers of employment and Business Skills immigrants who intend to establish business and meet certain capital requirements. Wooden (1991) reports refugees having more difficulty in finding 
employment than other immigrants. Despite the improvement in their relative outcomes a gap remains many years after arrival. Miller (1999) also reports higher unemployment rates among refugees and family sponsored immigrants compared to skilled based immigrants. Accounting for differences in human capital characteristics the gap for family sponsored immigrants disappears but a gap, albeit smaller, remains for refugees.

In the late 1990s Australian government established minimum age, skill, and English language criteria, started awarding additional points for spousal characteristics and degrees obtained in Australia that led to significant improvements in immigrants' human capital characteristics. Comparing the experiences of successive cohorts CobbClark (2006) concludes that improvements in human capital characteristics largely accounted for the improvements in participation and unemployment rates. During the period immigrant outcomes were improving in Australia, increasing poverty rates among immigrants are reported for Canada despite large improvements in their human capital characteristics. Hawthorne (2006) compares the labor market outcomes of skill based immigrants in Canada and Australia. While the outcomes were comparable in mid 1990s, Australian outcomes substantially improved following the adoption of new selection rules in the late 1990s.

The European context also offers further insights regarding the relative performance of immigrants by visa type. Constant and Zimmermann (2005a) find that, in Germany, former refugees and those that arrive through family reunification are less likely to work full time compared to those who came through the employment channel. In the Danish context, however, they find that the legal status at entry does not play any significant role. In a companion paper focusing on earnings, Constant and Zimmermann (2005b) find that arriving through family reunion or as asylum seekers or refugees has 
negative effects in both Germany and Denmark and legal status at entry have longlasting effects.

The available evidence on the relative labor market success of immigrants selected for their skills shows in general better or similar outcomes for skill based immigrants compared to other visa classes. However, there are signs of serious skill transferability problems that severely limit the extent to which higher observed skills are translated into more favorable labor market outcomes. Testing of qualifications, requiring a successful temporary work period to precede applications for permanent residency, targeting those with a degree obtained from the host country may lead to better labor market prospects among permanent skill based immigrants. However, currently these more successful practices generally apply to a small fraction of immigrants admitted. If the host countries were to admit a much larger fraction of immigrants through these specific selection processes supply may become a serious issue. The mixed evidence on relative labor market outcomes skilled workers shows that even after many years of experience the design of selection mechanisms remains as a challenging policy issue for receiving countries.

\section{Discussion}

There is growing interest worldwide in attracting highly skilled immigrants. The increasing importance of skills in knowledge based economies, aging of populations, and inferior labor market outcomes of existing immigrants are fueling this interest. New countries are entering the market for highly skilled workers while at the same time skilled immigration is gaining further importance in the immigration policies of 
traditional immigrant countries. As the competition for skills grow and barriers to mobility among highly skilled are reduced highly skilled individuals are able to choose between many alternative destinations. Aydemir and Robinson (2008) shows that a large fraction of male immigrants who are working age, especially among skilled workers and entrepreneurs, are highly internationally mobile and respond to the labor market prospects in the host country by return or onward migration.

In this setting expectations are high about the newly adopted selection mechanisms for the highly skilled among new players in this market. Traditional immigration countries, on the other hand, are trying to fine tune their existing selection systems with the hopes of improving the labor market outcomes of immigrants. While human capital characteristics draw the general framework for the various selection systems there is great heterogeneity across destination countries in the specifics. Relatively little is known from the experiences of European countries that recently started using points systems. The evidence from the traditional immigration countries shows that selecting immigrants generates a much higher skilled immigrant pool than would otherwise be achieved. However, translation of these higher skills into more favorable labor market outcomes, as expected, is not guaranteed. As many immigrants accumulate their human capital in countries that differ markedly from destination countries the biggest challenge is the transferability of human capital. Faced with this challenge destination countries are moving towards stricter admission requirements such as requiring the pre-migration credentials certification, occupations among a shortage list, and formal language testing. International students are also increasingly seen as an important source for recruiting immigrants. 
While these new developments show some promising signs for improving the labor market outcomes of the highly skilled they offer only partial solutions. For developing better policies we need careful evaluations of alternative selection mechanisms and a better understanding of the root causes of the difficult adaptation of highly skilled to the host country labor markets. These types of evaluations are starting to emerge as data with important identifiers of policy levers become more widely available. Variations in policy over time within host countries, as well as, growing differences in selection policies across countries provide a fertile background for advancing our understanding. Given the difficulties with the transfer of human capital and so long as destination countries admit immigrants based on family ties and humanitarian grounds, where screening is unlikely, the host countries also need to move beyond fine tuning selection mechanisms for the gainful addition of the immigrants to their economies. This requires careful attention to and development of the integration policies, an area that is largely overlooked although being crucial for the success of immigrants (Edin, et al. 2004).

Although there has been a lot of attention focused on labor market outcomes of different types of immigrants there are also wider less understood aspects of pursuing a skilled immigration policy. A number of recent papers investigate the important relation between growth in innovation and high skill immigration (e.g. Hunt, 2011, Kerr and Lincoln, 2010, Hunt and Gauthier-Loiselle, 2010). These broader consequences of skilled immigration may be very important for the surpluses created by immigration in host countries.

There are also important distributional consequences of immigration that needs consideration. The important role of immigration in distributing income among 
residents of the host country is tightly linked to the policy choices (Aydemir and Borjas, 2007). Finally, while skilled immigration policies are generally viewed from the perspective of receiving countries there are important consequences for immigrants and their source countries. These aspects may reveal that total gain in world output is not necessarily maximized through a restrictive skilled immigration policy. This calls for a careful analysis of the trade-offs involved in maximizing the gains for host countries and those for the world economy.

\section{References}

Antecol, Heather, Deborah Cobb-Clark and Stephen Trejo (2003), 'Immigration Policy and the Skills of Immigrants to Australia, Canada, and the United States', Journal of Human Resources, 38(1), 192-218.

Aydemir, Abdurrahman (2003), 'Effects of business cycles on the labour market assimilation of immigrants', in Charles Beach, Alan Green and Jeffrey Reitz (eds), Canadian Immigration Policy for the 21st Century, Montreal and Kingston: McGillQueen's University Press, 372-412

Aydemir, Abdurrahman (2006), 'International migration, self-selection and selection by host country: evidence from migration to Canada from the US and UK', mimeo.

Aydemir, Abdurrahman (2011), 'Immigrant Selection and Short-term Labour Market Outcomes by Visa Category', Journal of Population Economics, 24, 451-475 
Aydemir, Abdurrahman and George Borjas (2007), 'A Comparative Analysis of the Labor Market Impact of International Migration: Canada, Mexico, and the United States', Journal of the European Economic Association, 5(4), 663-708.

Aydemir, Abdurrahman and Christopher Robinson (2008), 'Global Labour Markets, Return and Onward Migration', Canadian Journal of Economics, 41(4), 1285-1311.

Aydemir, Abdurrahman and Mikal Skuterud (2005), 'Explaining the Deteriorating Entry Earnings of Canada's Immigrant Cohorts: 1966-2000', Canadian Journal of Economics, 38(2), 641-671.

Aydemir, Abdurrahman and Arthur Sweetman (2007), 'First and second generation immigrant educational attainment and labor market outcomes: a comparison of the United States and Canada', Research in Labor Economics, 27, 215-270.

Baker, Michael and Dwayne Benjamin (1994), 'The performance of immigrants in the Canadian labour market,' Journal of Labor Economics, 12, 369-405.

Baker, Michael and Dwayne Benjamin (1995), 'The receipt of transfer payments by immigrants to Canada', The Journal of Human Resources, 30, 650-677.

Barrett, Alan (1998), 'The effect of immigrant admission criteria on immigrant labourmarket characteristics', Population Research and Policy Review, 17(5), 439-456. 
Barrett, Alan and Yvonne McCarthy (2008), 'Immigrants and Welfare Programmes: Exploring the Interactions between Immigrant Characteristics, Immigrant Welfare Dependence and Welfare Policy', Oxford Review of Economic Policy, 24(3), 543-560.

Bauer, Thomas and Klaus F. Zimmermann (1997), 'Integrating the East: The Labor Market Effects of Immigration', in Sandra W. Black (ed.), Europe's Economy Looks East-Implications for the EU and Germany, Cambridge: Cambridge University Press, 269-306. Reprinted in: K. F. Zimmermann and T. Bauer (eds), The Economics of Migration, Cheltenham, Edward Elgar Publishing Ltd., 2002, IV(I), 123-160.

Bauer, Thomas , Magnus Lofstrom and Klaus F. Zimmermann (2000), 'Immigration policy, assimilation of immigrants, and natives' sentiments towards immigrants: evidence from 12 OECD countries', Swedish Economic Policy Review, 7, 11-53. Beach, Charles M., Alan G. Green and Christopher Worswick (2007), 'Impacts of the Point System and Immigration Policy Levers on Skill Characteristics of Canadian Immigrants', Research in Labor Economics, 27, 349-401.

Belot, Michéle V.K. and Timothy J. Hatton (2008), 'Immigrant Selection in the OECD', CEPR Discussion Papers 571, Centre for Economic Policy Research, Research School of Economics, Australian National University. 
Birrell, Bob, Lesleyanne Hawthorne and Sue Richardson (2006), 'Evaluation of the general skilled migration categories', Canberra, A.C.T.: Department of Immigration and Multicultural Affairs.

Bloom, David, Gilles Grenier and Morley Gunderson (1995), 'The changing labour market position of Canadian immigrants', Canadian Journal of Economics, 28, 9871005.

Borjas George (1985), 'Assimilation, changes in cohort quality and the earnings of immigrants', Journal of Labor Economics, 3, 463-489.

Borjas, George (1993), 'Immigration policy, national origin, and immigrant skills: a comparison of Canada and the United States', in David Card and Richard Freeman (eds), Small differences that matter, Chicago: The University of Chicago Press, 21-44.

Borjas, George (1995a), 'The Economic Benefits from Immigration', Journal of Economic Perspectives, 9(2), 3-22.

Borjas, George (1995b), 'Assimilation and changes in cohort quality revisited: what happened to immigrant earnings in the 1980s?', Journal of Labor Economics, 13(2), 201-245.

Borjas, George (1999), ‘The Economic Analysis of Migration', in Orley Ashenfelter and David Card (eds), Handbook of Labor Economics, 3A, North-Holland, 1697-760. 
Borjas, George (2009), 'Immigration in high-skill labor markets: The impact of foreign students on the earning of doctorates', in Richard Freeman and Daniel Goroff (eds), Science and Engineering Careers in the United States: An Analysis of Markets and Employment, Chicago: University of Chicago Press, 131-162.

Borjas, George and Rachel M. Friedberg (2009), 'Recent Trends in the Earnings of New Immigrants to the United States', NBER Working Papers no. 15406, National Bureau of Economic Research, Inc.

Borjas, George and Lynette Hilton (1996), 'Immigration and the Welfare State: Immigrant Participation in Means-Tested Entitlement Programs', Quarterly Journal of Economics, 111(2), 575-604.

Borjas George and Stephen Trejo (1991), 'Immigrant participation in the welfare system', Industrial and Labor Relations Review, 44(2), 195-211.

Borjas, George (1987), 'Self-Selection and the Earnings of Immigrants’, American Economic Review, 77(4), 531-53.

Causa, Orsetta and Sebastien Jean (2007), 'Integration of Immigrants in OECD Countries: Do Policies Matter?', OECD Economics Department Working Papers, no. 564, OECD Publishing. 
Chiswick, Barry R., Yew L. Lee and Paul W. Miller (2006), 'Immigrants' Language Skills and Visa Category', International Migration Review, 40(2), 419-450.

Clark, Ken and Stephen Drinkwater (2008), The labour-market performance of recent migrants, Oxford Review of Economic Policy, 24(3), 495-516.

Cobb-Clark, Deborah (1993), 'Immigrant Selectivity and Wages: The Evidence for Women', American Economic Review, 83(4), 986-993.

Cobb-Clark, Deborah (2000), 'Do selection criteria make a difference? Visa category and the labour market status of immigrants to Australia', Economic Record, 76(232), $15-31$.

Cobb-Clark, Deborah (2006), 'Selection Policy and the Labour Market Outcomes of New Immigrants', in Deborah Cobb-Clark and Siew-Ean Khoo (eds), Public Policy and Immigrant Settlement, Cheltenham, UK and Northampton, MA, USA: Edward Elgar Publishing, 27-52.

Constant, Amelie and Klaus F. Zimmermann (2005a), 'Legal status at entry, economic performance, and self employment proclivity: a bi-national study of immigrants', IZA Discussion Paper, no. 1910. 
Constant Amelie and Klaus F. Zimmermann (2005b), 'Immigrant performance and selective immigration policy: a European perspective', National Economic Review, 194(1), 94-105.

Constant, Amelie, Bienvenue N. Tien, Klaus F. Zimmermann and Jingzhou Meng (2013), 'China's Latent Human Capital Investment: Achieving Milestones and Competing for the Top', forthcoming in Journal of Contemporary China.

De Silva, Arnold (1997), 'Earnings of immigrant classes in the early 1980s in Canada: a reexamination', Canadian Public Policy, 23(2), 179-202.

Docquier, Frédéric and Abdeslam Marfouk (2006), 'International Migration by Educational Attainment, 1990-2000', in Caglar Ozden and Maurice Schiff (eds), International Migration, Remittances, and the Brain Drain, Washington, DC: The World Bank and Palgrave McMillan, 151-200.

Duleep, Harriett O. and Mark C. Regets (1992), 'Some evidence on the effect of admission criteria on immigrant assimilation', in Barry Chiswick (ed.), Immigration, language, and ethnicity, Washington: American Enterprise Institute, 410-439.

Duleep, Harriett O. and Mark C. Regets (1996), 'Admission Criteria and Immigrant Earnings Profiles', International Migration Review, 30(2), 571-590. 
Edin, Per-Anders, Peter Fredriksson and Olof Åslund (2004), 'Settlement Policies and the Economic Success of Immigrants', Journal of Population Economics, 17, 133- 155.

European Commission (2007), 'Attractive Conditions for the Admission and Residence of Highly Qualified Immigrants', MEMO/07/423, 23 October.

Fix, Michael and Jeffrey Passel (2002), ‘The Scope and Impact of Welfare Reform’s Immigrant Provisions', Washington, DC: The Urban Institute.

Grant, Mary (1999), 'Evidence of new immigrant assimilation in Canada', Canadian Journal of Economics, 32, 930-955.

Green, David and Alan G. Green (1995), 'Canadian Immigration Policy: The Effectiveness of the Point System and Other Instruments', Canadian Journal of Economics, 4b, 1006-1041.

Green, David and Christopher Worswick (2003), 'Immigrant earnings profiles in the presence of human capital investment: measuring cohort and macro effects', mimeo.

Grogger, Jeffrey and Gordon Hanson (2011), 'Income Maximization and the Selection and Sorting of International Migrants', Journal of Development Economics, 95(1), 4257. 
Hansen, Jorgen and Magnus Lofstrom (2003), 'Immigrant assimilation and welfare participation: Do immigrants assimilate into or out-of welfare?', Journal of Human Resources, 38(1), 74-98.

Hanson, Gordon (2010), 'The Governance of Migration Policy', Journal of Human Development and Capabilities, 11(2), 185-208.

Hawthorne, Lesleyanne (2006), 'Labour market outcomes for migrant professionals: Canada and Australia compared', Citizenship and Immigration Canada.

Hijzen, Alexander and Peter W. Wright (2010), 'Migration, trade and wages', Journal of Population Economics, 23, 1189-1211.

Hunt, Jennifer (2011), 'Which immigrants are most innovative and entrepreneurial? Distinctions by entry visa', Journal of Labor Economics, 29, 3.

Hunt, Jennifer and Marjolaine Gauthier-Loiselle (2010), 'How much does immigration boost innovation?', American Economic Journal: Macroeconomics, 2(2), 31-56.

Jandl, Michael (2003), 'Estimates on the numbers of illegal and smuggled immigrants in Europe', International Center for Migration Policy Development, 8th International Metropolis Conference, Vienna. 
Jasso, Guillermina and Mark R. Rosenzweig (1995), 'Do immigrants screened for skills do better than family reunification immigrants?', International Migration Review, 29(1), 85-111.

Kahanec, Martin and Klaus F. Zimmermann (2011), 'High-Skilled Immigration Policy in Europe', in Barry R. Chiswick (ed.), High-Skilled Immigration in a Global Labor Market, Washington, DC: American Enterprise Institute, 264-314.

Kerr, William R. and William F. Lincoln (2010), 'The supply side of innovation: H-1B visas and US ethnic invention', Journal of Labor Economics, 28(3), 473-508.

Li, Peter S. (2003), 'Initial earnings and catch-up capacity of immigrants', Canadian Public Policy, 29(3), 319-337.

Lofstrom, Magnus and Joseph J. Hayes (2011), 'H-1bs: How Do They Stack Up to US Born Workers?', IZA Discussion Paper no. 6259.

Lubostky, Darren (2007), 'Chutes or ladders? A longitudinal study of immigrant earnings', Journal of Political Economy, 115(5), 820-867.

Marr, Bill and Pierre Siklos (1999), 'Immigrant Class and the Use of Unemployment Insurance by Recent Immigrants in Canada: Evidence from a New Data Base, 1980 to 1995', International Migration Review, 33(3), 561-593. 
McDonald, Ted and Christopher Worswick (1999), 'The earnings of immigrant men in Australia: assimilation, cohort effects and macroeconomic conditions', The Economic Record, 75, 49-62.

Miller, Paul W. (1999), 'Immigration Policy and Immigrant Quality: The Australian Point System', American Economic Review, 89(2), 192-197.

OECD (2005), ‘Trends in International Migration', Paris: OECD.

OECD (2008), 'International Migration Outlook', Paris: OECD.

OECD (2011), 'International Migration Outlook', Paris: OECD.

Passel, Jeffrey S. (2006), 'Size and Characteristics of the Unauthorized Population in the US: Estimates from the March 2005 Current Population Survey', Washington, DC: Pew Hispanic Center.

Picot, Garnett and Feng Hou (2008), 'Poverty Dynamics among Recent Immigrants to Canada', International Migration Review, 42(2), 393-424.

Richardson, Sue and Laurence Lester (2004), 'A Comparison of Australian and Canadian Immigration Policies and Labour Market Outcomes', Report to the Department of Immigration and Multicultural and Indigenous Affairs, National Institute of Labour Studies, Flinders University. 
Riphahn, Regina T. (2004), 'Immigration Participation in Social Assistance Programs', Applied Economics Quarterly, 50(4), 329-362.

Rosholm, Michael, Kirk Scott and Leif Husted (2006), 'Times They Are-A Changin':

Declining Immigrant Employment Opportunities in Scandinavia', International Migration Review, 40(2), 318-347.

Rowthorn, Robert (2008), 'The Fiscal impact of immigration on the advanced economies', Oxford Review of Economic Policy, 24(3), 560-580.

Ruhs, Martin (2008), 'Economic research and labour immigration policy', Oxford Review of Economic Policy', 24(3), 403-426.

Smith, James P. and Barry Edmonston, (eds) (1997), 'The New Americans: Economic, Demographic and Fiscal Effects of Immigration', Washington, DC: National Research Council, National Academy Press.

Storesletten, Kjetil (2000), 'Sustaining Fiscal Policy through Immigration', Journal of Political Economy, 108(2), 300-24.

Teicher, Julian, Chandra Shah and Gerard Griffin (2002), 'Australian Immigration: The Triumph of Economics over Prejudice?', International Journal of Manpower, 23(3), 209-36. 
Wadhwa, Vivek, AnnaLee Saxenian, Ben Rissing and Gary Gereffi (2008), 'Skilled Immigration and Economic Growth', Applied Research in Economic Development, 5(1), 6-13.

Wanner, Richard A. (2003), 'Entry Class and the Earnings Attainment of Immigrants to Canada, 1980-1995', Canadian Public Policy, 29(1), 53-71.

Wooden, Mark (1991) 'The Experience of Refugees in the Australian Labour Market', International Migration Review, 35(3), 514-35.

\footnotetext{
${ }^{i}$ Rowthorn (2008) surveys the fiscal impacts of immigration focusing on the advanced economies.

${ }^{\text {ii }}$ See for further reference the chapter on Attitudes Towards Migrants in this volume.

iii Free migration accounts around $20 \%$ of total migration in France, the UK and Netherlands, between 30 $\%$ and $40 \%$ in Norway, Sweden and Finland, and around $50 \%$ or more for Austria, Denmark, Belgium, Germany and Switzerland.

${ }^{\text {iv }}$ See for further reference the chapter on Human Smuggling in this volume.

${ }^{v}$ As a special case of skilled migration see the chapter on Migration of Health Professionals in this volume for further reference.

${ }^{\text {vi }}$ See Green and Green, 1995 for an excellent discussion of the Canadian points system.

${ }^{\text {vii }}$ The importance of attracting skilled immigrants is also gaining recognition at the EU level as exemplified by the European Commission's recent proposal for a 'Blue Card' for highly skilled non-EU workers. The proposed scheme would grant migrants a series of socio-economic rights and favorable conditions for family reunification. (European Commission, 2007). For a review of high skill immigration policies in Europe see Kahanec and Zimmermann (2011).

viii During the 2000-2001 period $66 \%$ of immigrants were admitted under skill requirements in Canada. Around this period $51 \%$ of immigrants in Australia were admitted under skill requirements and $17 \%$ in the US based on employment preferences.
} 
${ }^{\text {ix }}$ Note that points system potentially affects the skill composition of immigrants through two channels: by changing the country of origin composition of immigrants and by selecting immigrants with different skills within countries of origin. The importance of these channels may have changed over time. The launch of the point system in Canada in 1967 may have initially resulted large shifts in country of origin composition since national quota system prior to 1967 restricted migration primarily to preferred countries (UK, US, France and some Commonwealth countries) and northwestern Europe. This impact may have become smaller as the weight of source regions prior to 1967 declined. Borjas (1993) focuses on the stock of immigrants who arrived starting from 1960s until 1981, while Aydemir (2011) focuses on a cohort that arrived over 2000-2001. Over time, in addition to the changing source country distribution of immigrants the importance of education in determining eligibility in the point system has increased considerably. These differences may explain different conclusions regarding the role of the point system.

${ }^{\mathrm{x}}$ Only recently the Canadian points system started to explicitly award points for partner's education, arranged employment and previous study in Canada.

${ }^{x i}$ For further reference on refugees see the chapter on Refugee Migration in this volume.

xii For males, among these characteristics only speaking ability has a positive impact on labor market outcomes while the other factors including reading and writing ability has no positive impacts. We should note that for the immigrant cohorts studied here no formal testing of language ability was required during applications for permanent residence.

xiii The small or insignificant returns to human capital characteristics obtained abroad have been also reported for recent immigrants by other studies (see, e.g. Aydemir and Skuterud, 2005). 